\title{
Transpiration of young cocoa trees under soil water restriction
}

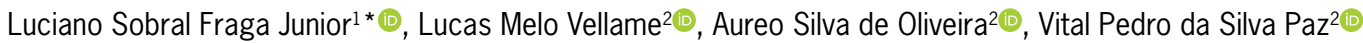

\author{
'Universidade de São Paulo/ESALQ - Depto. de Engenharia \\ de Biossistemas, Av. Pádua Dias, 11 - 13418-900 - \\ Piracicaba, SP - Brasil. \\ 2Universidade Federal do Recôncavo da Bahia/Centro de \\ Ciências Agrárias e Ambientais, R. Rui Barbosa, 710 - \\ 44380-000 - Cruz das Almas, BA - Brasil. \\ ${ }^{*}$ Corresponding author <lucianosobral@usp.br>
}

Edited by: Mohammad Valipour

Received April 16, 2019

Accepted September 01, 2019
ABSTRACT: Cocoa plantations in Brazil have been expanding beyond the borders of traditional regions by implementing a strategy based on irrigation and the establishment of crops exposed to full sunlight. The quantification of transpiration is essential to the establishment and management of crops, and is the main factor in the determination of water demand. This study had as its objective the estimating of transpiration of young cocoa trees as a function of reference evapotranspiration (ETo) and soil matric potential ( $\Psi w)$. Two experiments were conducted, one in a greenhouse and the other in the field, using clones and seminal plants. Soil water content, plant transpiration and reference evapotranspiration were monitored. Cocoa trees were subjected to soil moisture reduction and their transpiration decreased linearly both in the field and in the greenhouse, due to decreases in the soil matric potential beyond a critical point. In the greenhouse average transpiration could be linearly estimated as a function of ETo when $\Psi$ w was higher than $-24.89 \mathrm{kP}$. Drying soil conditions resulted in a reduction in transpiration by approximately a $2 \%$ per unit decrease in $\Psi \mathrm{w}$. Under field conditions; clonal plant transpiration decreased linearly beyond the critical matric potential of $-65.02 \mathrm{kPa}$, while in seminal plants this reduction occurred beyond $-79.48 \mathrm{kPa}$. Clonal plants were more sensitive to soil water variations with average transpiration lower than that of seminal cocoa tree plants.

Keywords: Theobroma cacao L., sapflow, evapotranspiration, water deficit

\section{Introduction}

According to data from the International Cocoa Organization (ICCO, 2017), Brazil is the seventh largest producer of cocoa in the world, whose harvest for the year 2018/19 is estimated at approximately 204,000 tons of almonds. The traditional regions of cocoa cultivation in the country are concentrated in the states of Pará and Bahia, which together account for approximately $94 \%$ of production (Conab, 2018). These so-called traditional regions are characterized by a humid climate and the regular distribution of rainfall during most of the year, as well as by the adoption of an agroforestry production system denominated regionally as "cabruca" in which the cocoa beans are cultivated in consortium with the forest natives (Piasentim and Saito, 2014).

A few decades ago, these regions were affected by phytosanitary problems difficult to solve on account of the microclimate in crops that favors the spread of fungal diseases as well as the high cost and inefficiency of chemical control (Leite et al., 2013). For this reason, cocoa plantations have been expanding in areas with characteristics very distinct from those of traditional cocoa plantation areas, where success has been achieved by managing the crop with regular spacing, micro irrigation, fertigation, and genetically enhanced material (Leite et al., 2013).

Under these conditions cocoa plantations have been successfully managed by producers with no recourse to reliable information on the water consumption of the crop. This is due as much to the scarcity of categorical information in the literature, given the many works available presenting conflicting results and conclusions drawn on the interaction of the cocoa tree with its environment (Rada et al., 2005; Baligar et al., 2008; Köhler et al., 2009). These results are influenced by the spatial and temporal variability of the main variables governing the process of water transfer in the soil-plantatmosphere system. Thus, it is important to investigate the various water relationships between cocoa trees and different climatic conditions, soil and crop management.

The quantification of transpiration is essential to a determination of water demand for perennial plants, especially those which are micro irrigated, where evaporation is minimized. In the case of cocoa trees, since they are a deciduous plant, a sizeable quantity of leaves is deposited on the soil, which further reduces the loss of water through evaporation. The determination of sap flow using Granier's method (Granier, 1985) allows for the quantification of transpiration on a daily basis, as well as the study of relationships between transpiration and environmental factors and the resulting influence on a fine temporal scale (Vellame et al., 2012). This study brings together the results of transpiration and environmental measurements of two experiments, one in the field and the other in a greenhouse, with the purpose of obtaining a comparison of the measurements. The aim of this work was to estimate the transpiration of cocoa trees as a function of atmospheric water demand and soil available water.

\section{Materials and Methods}

Two experiments were conducted using cocoa plants, one in the field and the other in a greenhouse. After conducting the first experiment under field conditions, the need to perform a new experiment in a greenhouse with a larger number of plants was evaluated in order 
to validate and compare the previously obtained results. For the experiment in the greenhouse, it was necessary to install the entire structure as well as the preparation of cocoa seedlings. From inception to data collection and analysis, there was a four-year gap between the two experiments, a relatively short period for perennial plants. Soil water content, leaf area, plant transpiration and reference evapotranspiration were monitored in both experiments.

\section{Field experiment}

The experiment was carried out at an experimental site with 7-year-old cocoa plants in full sunlight, with $1.5 \times 3.5 \mathrm{~m}$ spacing. The plantation is situated in the municipality of Nova Redenção, in the state of Bahia, at $12^{\circ} 51^{\prime} 46^{\prime \prime} \mathrm{S}, 41^{\circ} 08^{\prime} 14^{\prime \prime} \mathrm{W}$, altitude of $350 \mathrm{~m}$. The climate is considered Bswh (semi-arid) according to Köppen's classification (Dubreuil et al., 2017), characterized by its yearly average temperature of $23^{\circ} \mathrm{C}$, with a maximum of $27^{\circ} \mathrm{C}$, minimum of $18{ }^{\circ} \mathrm{C}$ and rainfall of $600 \mathrm{~mm}$. The experimental site location is shown in Figure 1.

The soil at the site is classified as eutrophic Cambisol of clay loam texture, with good drainage and average fractions of $43 \%$ sand, $23 \%$ clay and $34 \%$ silt. The transpiration of six plants $/ 4$ seminal plants and $2 \mathrm{CCN} 51$ clones) was measured with no irrigation. In addition to transpiration, soil moisture and meteorological elements were also monitored. Data collection was initiated on Feb 2, 2011, and terminated on Apr 14, 2012.

\section{Greenhouse experiment}

The experiment was carried out in a greenhouse with plastic covering, in the municipality of Cruz das Almas, in the state of Bahia $\left(12^{\circ} 48^{\prime} \mathrm{S} ; 39^{\circ} 06^{\prime} \mathrm{W} ; 225 \mathrm{~m}\right.$ altitude). The local climate is classified as humid to semi humid, with average annual rainfall of $1143 \mathrm{~mm}$ and average annual temperature $24.5^{\circ} \mathrm{C}$.

Forty clones of CCN51 plants with CEPEC2002 rootstocks were used, which were grafted in Apr of 2015 and transplanted on Mar 20, 2016, in 0.5- $\mathrm{m}^{3}$ soil containers. The soil is classified as sandy loam, with $1.31 \mathrm{~g} \mathrm{~cm}^{-3}$ density, $51 \%$ porosity and granulometry consisting of $68 \%$ sand, $20 \%$ silt and $12 \%$ clay.

Each container had a drainage system consisting of a 0.025-m-diameter drain, a 0.08-m-thick layer of crushed stone, a nylon screen and a 0.01-m-thick layer of washed sand.

Data on soil water potential and transpiration from the 40 clones were collected, along with meteorological data from inside the greenhouse. Data collection was initiated 180 days after transplanting (21 Sept 2016) and terminated on Nov 17, 2016.

The completely randomized experiment was divided into two stages. During the first stage, which lasted18 days, soil moisture was kept close to field capacity for all plants in order to maintain potential transpiration. During the second stage, which lasted 21 days, the soil was maintained close to field capacity for half of the plants, while irrigation was suspended for the other half, thus ensuring a progressive decrease in soil matric potentials as a result of evapotranspiration.

\section{Transpiration}

Plant transpiration was estimated based on sapflow using the Thermal Dissipation Probe (TDP) method (Granier, 1985). Probes $1 \mathrm{~cm}$ and $2 \mathrm{~cm}$ in length were constructed and heated with a power supply. The probes were installed in the rootstock, 6 to $8 \mathrm{~cm}$ above the soil, maintaining a distance of $8 \mathrm{~cm}$ between probes.
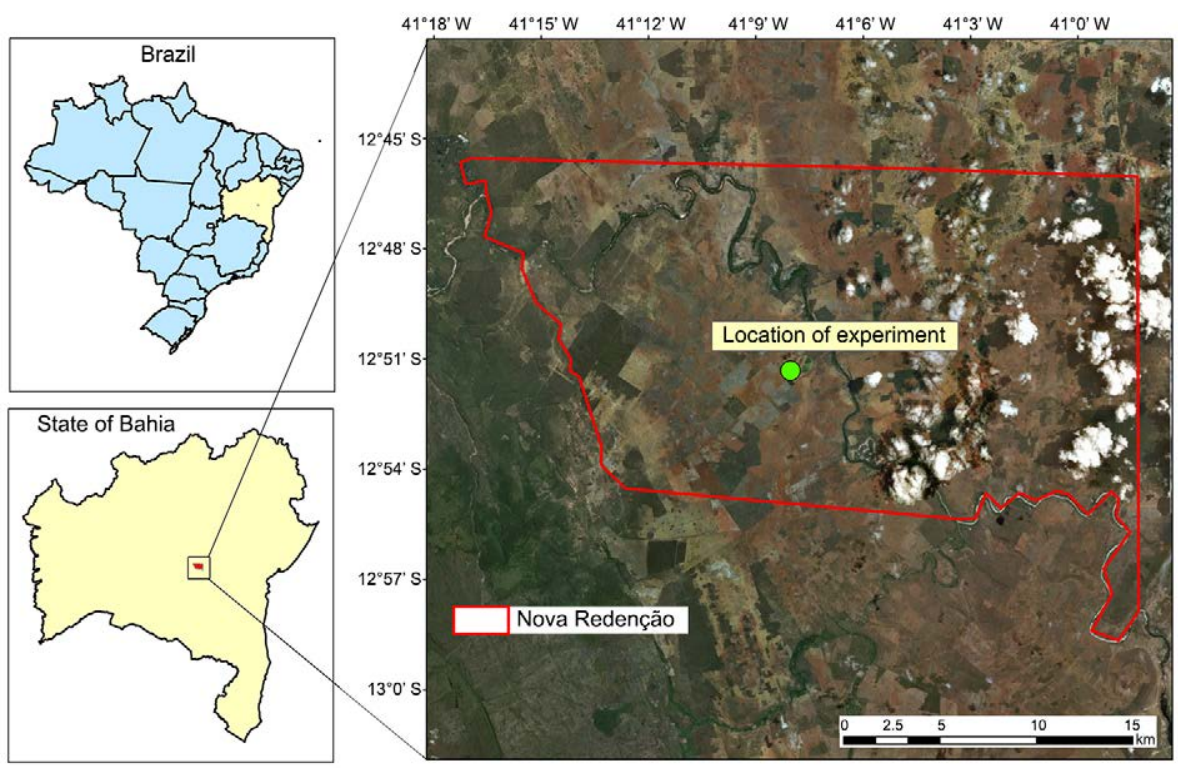

Figure 1 - Location of the experimental area in a cocoa plantation in the state of Bahia, Brazil. 
To calibrate the TDP for transpiration estimation, three weighing lysimeters, consisting of soil containers and 1000-kg-capacity weighing platforms were used. The lysimeters were calibrated in five cycles of loading and unloading with known weights. The margin for error in the measurements $(p<0.05)$ was less than $1 \%$. In order to avoid water loss by evaporation the lysimeters were covered with plastic tarps. This limited measurement taking to plant transpiration only. Granier's angular coefficient of equation (1985) was adjusted to minimize the absolute deviations between the 24-h-accumulated sapflow and transpiration as measured by the lysimeters.

$F=0.000357\left(\frac{\Delta T_{\max }-\Delta T}{\Delta T}\right)^{1.231} S A$

where: $F$ - sapflow, $\mathrm{m}^{3} ; \Delta T$ - temperature difference between probes, ${ }^{\circ} \mathrm{C} ; \Delta T_{\max }$ - temperature difference between probes at zero sapflow, ${ }^{\circ} \mathrm{C} ; S A$ - stem sapflow area, $\mathrm{m}^{2}$.

Stem sapflow area $\left(\mathrm{SA}-\mathrm{cm}^{2}\right)$ was estimated using Eq. 2 as a function of the stem outer perimeter $(\mathrm{Pe}-\mathrm{cm})$. Thus, transversal cuts were made in branches of different diameters in a single plant to obtain images of the sections and define the main anatomical structures of the stem.

$\mathrm{SA}=-0.0004 \mathrm{Pe}^{2}+1.1367 \mathrm{Pe}-4.8927\left(\mathrm{R}^{2}=0.999\right)$

To attenuate the natural thermal gradients (NTG), the stems were covered with laminated paper immediately above the upper probe, as well as below the lower probe. The probes were also protected by the paper being folded in a skirt-like shape.

\section{Reference Evapotranspiration (ETo)}

Meteorological data for the experiment were collected by an automatic weather station installed 100 $\mathrm{m}$ away from the experimental site. It measured global solar radiation, air temperature and relative humidity, wind speed and rainfall.

In the center of the greenhouse, solar radiation, air temperature and relative humidity were measured.

Meteorological data were used to obtain the daily reference evapotranspiration (ETo) through the PenmanMonteith equation, as parametrized by the FAO (Allen et al., 1998). Wind speed inside the greenhouse was fixed at $0.5 \mathrm{~m} \mathrm{~s}^{-1}$, as recommended by FAO's paper 56 for conditions in which this element is practically zero (Allen et al., 1998).

\section{Soil water}

In the greenhouse experiment, soil water potential was determined using tensiometers installed $0.20 \mathrm{~m}$ deep in each soil container. The readings were taken daily at 2 p.m. using a digital tensimeter.

In the field, soil water content was estimated using the model proposed by Ledieu et al. (1986), which relates the soil dielectric constant to its moisture. The dielectric constant (Ka) was estimated using the Time-Domain
Reflectometry (TDR) technique. Ka was estimated by the emission/reflection time of an electromagnetic pulse emitted by a pulse generator to parallel metal rods serving as waveguides.

The TDR waveguides were installed vertically in the soil with horizontal distances of $10 \mathrm{~cm}$ and vertical distances of $10 \mathrm{~cm}, 30 \mathrm{~cm}, 50 \mathrm{~cm}$ and $70 \mathrm{~cm}$, with two repetitions, one in clonal plants and other in seminal plants. With the moisture data read by the TDR, the average moisture profile was identified and the soil matric potential calculated using the water retention curve (Eq. 3). The water retention curve was given by the relationship between the soil moisture and the matric potential of undisturbed soil samples using the methodology proposed by Richards (1965).

$\psi=1.010^{-7} \theta^{-13.76}$

where: $\psi$ - matric potential, $\mathrm{kPa}$; and $\theta$ - soil moisture, $\mathrm{cm}^{3} \mathrm{~cm}^{-3}$

\section{Data acquisition and analysis}

For the measurement and storage of meteorological, weighing platform and TDP data in the greenhouse a CR1000 datalogger with two AM16/32 Relay Multiplexers was used.

In the field a CR1000 datalogger was also used for the meteorological data. Soil moisture data were obtained using a system comprising a TDR 100 Reflectometer, linked to a SDMX50 8 channel multiplexer with data storage in a CR1000 datalogger. This datalogger was also used to measure and store the TDP data. All dataloggers were programmed to read the sensors every $30 \mathrm{~s}$ and store the average at 15 -min intervals.

The expected transpiration percentage of the plants in the greenhouse (PTr) was calculated by the ratio between the real transpiration of the plants under water deficit $\left(\operatorname{Tr}_{\text {real }}\right)$ and the expected transpiration $\left(\operatorname{Tr}_{\text {exp }}\right)$ for these plants, in cases where they were being irrigated (Eq. 4). The expected transpiration was calculated based on the average transpiration of the irrigated plants (Eq. 5).

$$
\begin{aligned}
& \operatorname{PTr}=\frac{T r_{\text {real }}}{\operatorname{Tr}_{\text {exp }}} \times 100 \\
& \operatorname{Tr} \exp =\frac{T r_{\text {initial }}}{T r_{\text {initial_average }}} \times T r_{\text {current_average }}
\end{aligned}
$$

where: $\operatorname{Tr}_{\text {initial }}$ - average transpiration of the plant at the first stage (frequent irrigation), $\mathrm{L} \mathrm{d}^{-1} ; \operatorname{Tr}_{\text {initial_average }}$ - average transpiration of the group of plants irrigated at the first

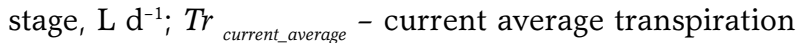
of the group of frequently irrigated plants, $\mathrm{L} \mathrm{d}^{-1}$.

Variance and means tests were carried out for the transpiration $\left(\mathrm{L} \mathrm{d}^{-1}\right)$ data, using the leaf area and soil matric potential as sources of variation. Tukey's test with a probability of $5 \%$ was used to differentiate the means of these variables. Regression analysis was used to establish the relationship between the average 
transpirations of the irrigated plants and drying-soil plants with ETo and with the soil matric potential.

The percentage of the expected transpiration and soil matric potential were correlated through a segmented regression analysis, minimizing the root mean square error (RMSE) between the observed and the calculated transpiration percentages (Vellame et al., 2015), thus defining the soil matric potential from which there is a linear reduction in the expected transpiration. The values observed and estimated by the segmented regressions were correlated by linear regression and the Mayer et al. test (1994). In addition to determining the degree of relationship between the model outputs and real data, this analysis can simultaneously provide a unit slope and zero intercept.

\section{Results}

\section{Greenhouse experiment}

Through regression analysis of the relationship between the mean daily transpiration of the groups of plants submitted to soil drying and those under frequent irrigation, it was observed that the variables presented a linear relationship and that the coefficients were significantly different $(p<0.001)$ for unit slope and zero intercept, demonstrating the difference between the groups of plants as regards transpiration (Table 1).

The relationship between ETo and plant transpiration showed that plants under frequent irrigation usually had higher transpiration than those in drying soil subjected to various atmospheric water demands (Figure 2).

In a short period of soil moisture reduction $(21$ days), it was possible to see physiological alterations in the cocoa trees beginning at $-40 \mathrm{kPa}$ of soil matric potential $(\Psi \mathrm{w})$, such as loss of leaf turgidity, yellowing, drying leaves and senescence of the lower leaves. These effects could be attributed to certain characteristics such as low soil water extraction capacity of the root system, low hydraulic conductivity of the plant tissue and/or low efficiency of the stomatal resistance (Figure 3).

With segmented linear regression it was possible to observe that, beyond the $\Psi \mathrm{w}$ of $-24.89 \mathrm{kPa}$ (considered a critical value), the expected transpiration tended to decrease linearly by approximately a $2 \%$ per unit decrease in $\Psi_{\mathrm{w}}$ (Figure 4).

Table 1 - Regression analysis $(Y=a+b X)$ between sap flow of cocoa plants under soil drying and frequent irrigation conditions.

\begin{tabular}{lc}
\hline & Regression analysis \\
\hline Intercept $(a) \pm S D$ & $-1.41161 \pm 0.67417$ \\
Slope $(b) \pm S D$ & $1.31551 \pm 0.21846$ \\
Adjusted $R^{2}$ & 0.63809 \\
RMSE & 0.37802 \\
$p$ value for & 0.00010 \\
HO: $a=0$ and $b=1$ & \\
\hline
\end{tabular}

$\mathrm{SD}=$ Standard Deviation; RMSE = Mean Square Root Error.

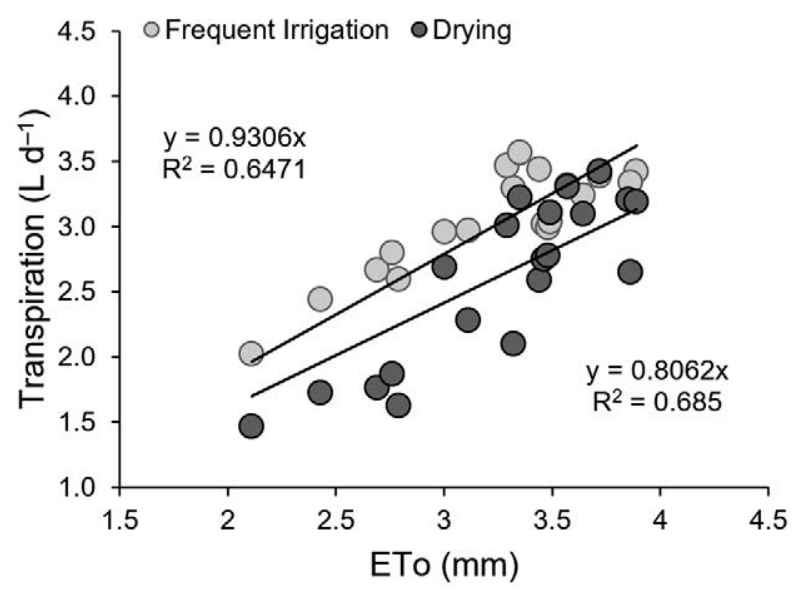

Figure 2 - Relationship between reference evapotranspiration (ETo) and average daily transpiration of cocoa trees under frequent irrigation (light dots) and under drying soil (dark dots) during stage 2.

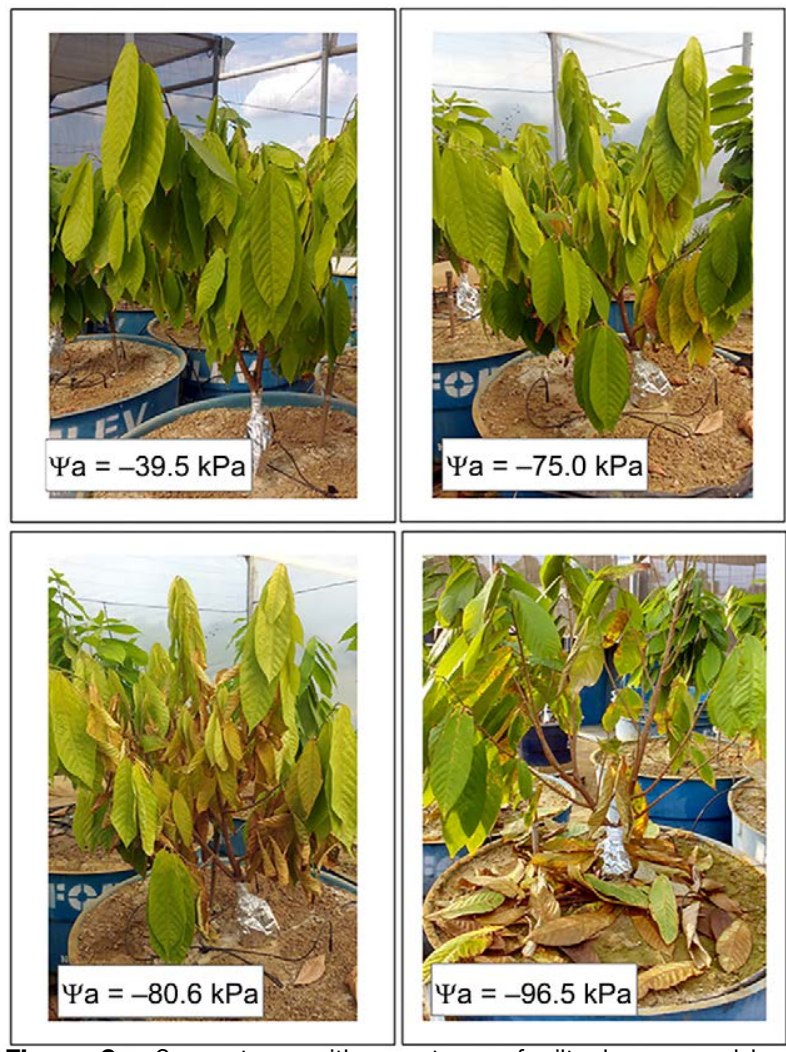

Figure 3 - Cocoa trees with symptoms of wilt, dryness and leaf senescence caused by the reduction of soil matric potential ( $\Psi w)$.

The segmented linear regression model was adequate since the variables showed little dispersion (Adjusted $\mathrm{R}^{2}=0.93121$ ) and the coefficients did not differ significantly ( $p>0.9999$ ) either in terms of unit slope or in regression analysis in terms of observed and estimated values of the expected transpiration zero intercept. The root mean square error (RMSE) for the model was $5 \%$ of the expected transpiration (Table 2). 


\section{Field experiment}

During the observation period, there were two distinct phases of increase and reduction in soil moisture caused by the rainfall distribution during the experiment. A lag was observed between the rainfall period and the increase in moisture in the upper layer of the soil $(0-10 \mathrm{~cm}$ deep). Moisture variation was observed only three days after the start of the rainfall, when total precipitation reached $40 \mathrm{~mm}$, due to the interception of the rain by the canopy and the leaves deposited on the soil which formed a 25-mm-thick layer (Figure 5).

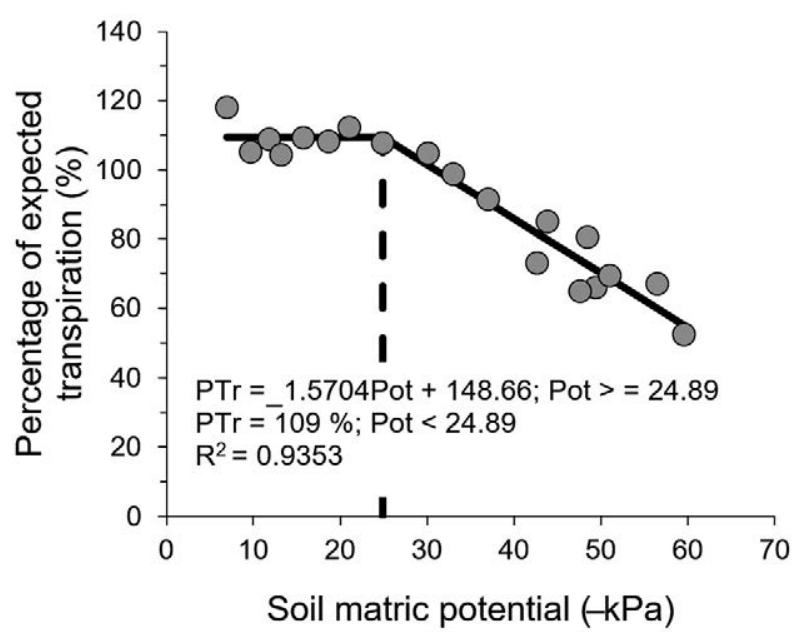

Figure 4 - Relationship between expected cocoa transpiration and soil matric potential.
During the first stage over time, the variation in the ratio between transpiration and reference evapotranspiration (Tr/ETo) was similar to variations in soil moisture, with greater amplitude in seminal plants than in cloned ones; however, during the second stage this similarity was not observed.

In the averages presented, a sapflow difference between the analyzed varieties and the soil moisture variation stages was observed, but there was no difference between stages for each variety. Sapflow was $38 \%$ and $69 \%$ lower in the clones than in the seminal plants at both the first and second stages, respectively (Table 3).

CCN51 cocoa clones kept their transpiration and reference evapotranspiration ratio (Tr/ETo) at approximately $4.27 \mathrm{~L} \mathrm{~mm}^{-1} \mathrm{~d}^{-1}$ up to a soil matric potential $(\Psi \mathrm{w})$ higher than $-53.97 \mathrm{kPa}$; beyond this point there was a linear reduction in the Tr/ETo ratio (Figure 6A). For seminal plants the $\mathrm{Tr} /$ ETo ratio was higher than in the clones, with an average value of $5.19 \mathrm{~L} \mathrm{~mm}^{-1} \mathrm{~d}^{-1}$

Table 2 - Regression analysis $(Y=a+b X)$ between observed and estimated of expected cocoa transpiration by the segmented regression model.

\begin{tabular}{lc}
\hline \multicolumn{2}{c}{ Regression analysis } \\
\hline Intercept $(\mathrm{a}) \pm \mathrm{SD}$ & $0.04046 \pm 5.93592$ \\
Slope $(\mathrm{b}) \pm \mathrm{SD}$ & $0.99955 \pm 0.06390$ \\
Adjusted $\mathrm{R}^{2}$ & 0.93121 \\
RMSE & 5.29419 \\
$p$ value for & 0.99998 \\
$\mathrm{HO}: \mathrm{a}=0$ and $\mathrm{b}=1$ &
\end{tabular}

$\mathrm{SD}=$ Standard Deviation; RMSE $=$ Mean Square Root Error.

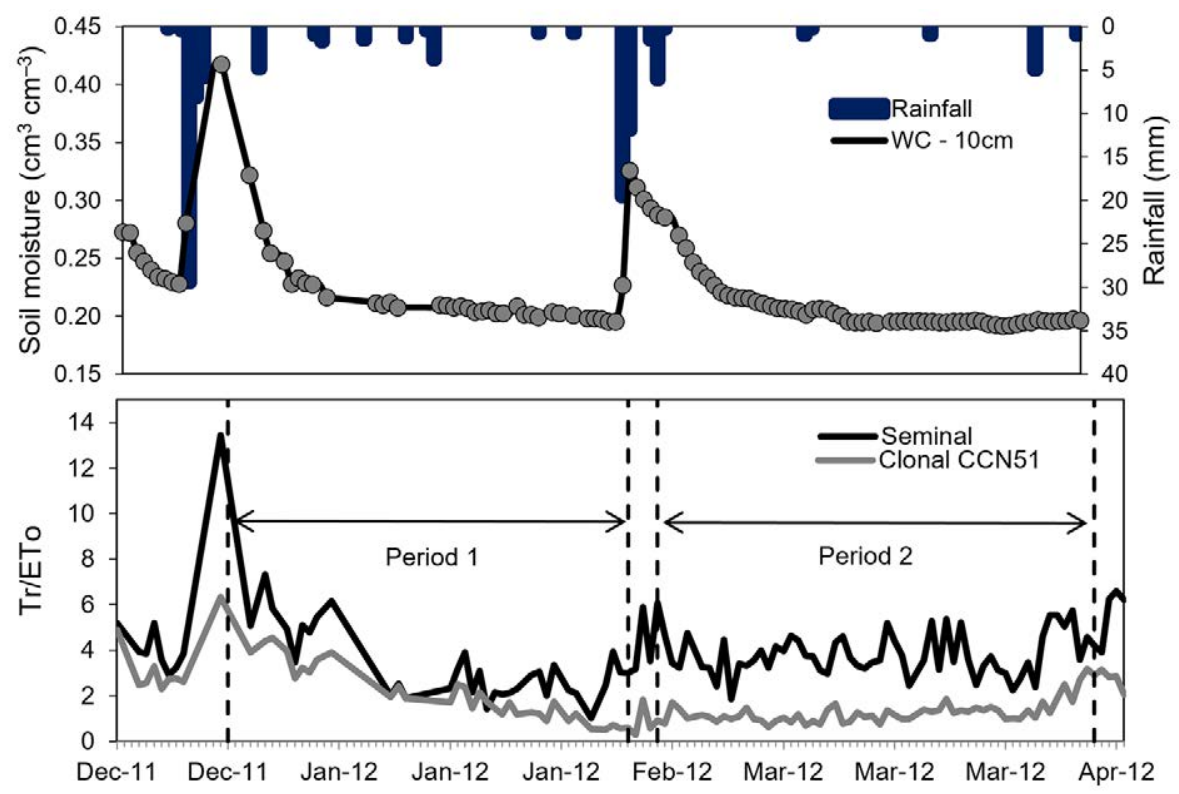

Figure 5 - Soil moisture and rainfall (above), and transpiration and reference evapotranspiration ratio ( $\operatorname{Tr} / \mathrm{ETo}$ ) in the seminal and clonal cocoa plants (below), during the interval from Dec 2011 to Apr 2012. 
at $\Psi_{\mathrm{w}}$ higher than $-79.48 \mathrm{kPa}$; beyond this point there was also a linear reduction in transpiration as a function of the soil matric potential (Figure 6B).

Reviewing the values presented, it should be highlighted that the seminal plants maintained transpiration at higher rates compared to clonal plants up to a much lower $\Psi_{\mathrm{w}}$, both with reduction after the $\Psi_{\mathrm{w}}$ which was considered as critical points (-53.97 $\mathrm{kPa}$ for the clones and $-79.48 \mathrm{kPa}$ for the seminal plants). It was observed from the angular coefficients of the regression analysis, that the reductions in $\mathrm{Tr} / \mathrm{ETo}$ were less accentuated in the seminal plants $(-0.0206)$ compared to the CCN51 (-0.0494).

Segmented linear regression models were adequate once estimated transpiration had shown low dispersion in relation to the values observed with Adjusted $\mathrm{R}^{2}$ of 0.82 for clonal and 0.67 for seminal plants (Table 4). The linear and angular coefficients did not differ significantly from zero and unit, respectively. The root mean square error (RMSE) for segmented regression of clonal plants was $0.53 \mathrm{~L} \mathrm{~mm}^{-1} \mathrm{~d}^{-1}$, while for the seminal plants it was $0.79 \mathrm{~L} \mathrm{~mm}^{-1} \mathrm{~d}^{-1}$ due to greater variability in transpiration in this group.

\section{Discussion}

At stage 1 of the field experiment, the higher amount of precipitation favored higher Tr/ETo ratios, while the dry spell at the end of the same stage, along with the senescence of leaves and soil water distribution, resulted in a reduction in transpiration, even with the rainfall at the beginning of Stage 2. For Wang et al. (2017) and Borden and Isaac (2019), these factors influence the phenotypic plasticity and, consequently, the adjustment of soil water usage by woody plants. The cocoa tree is physiologically affected when the amount of soil water

Table 3 - Sapflow averages of the seminal and clonal cocoa plants during two stages of increase and reduction of soil moisture (stages 1 and 2).

\begin{tabular}{lccc}
\hline \multirow{2}{*}{ Variety } & \multicolumn{3}{c}{ Sapflow $\left(\mathrm{L} \mathrm{d}^{-1}\right)$} \\
\cline { 2 - 4 } & Stage 1 & Stage 2 & Average \\
\hline Clone & $1.28 \mathrm{bA}$ & $0.75 \mathrm{bB}$ & $0.9976 \mathrm{~b}$ \\
Seminal & $2.07 \mathrm{aA}$ & $2.49 \mathrm{aB}$ & $2.3316 \mathrm{a}$
\end{tabular}

Averages followed by same letters, lowercase in the columns and uppercase in the rows, do not differ statistically (Tukey $<5 \%$ ).
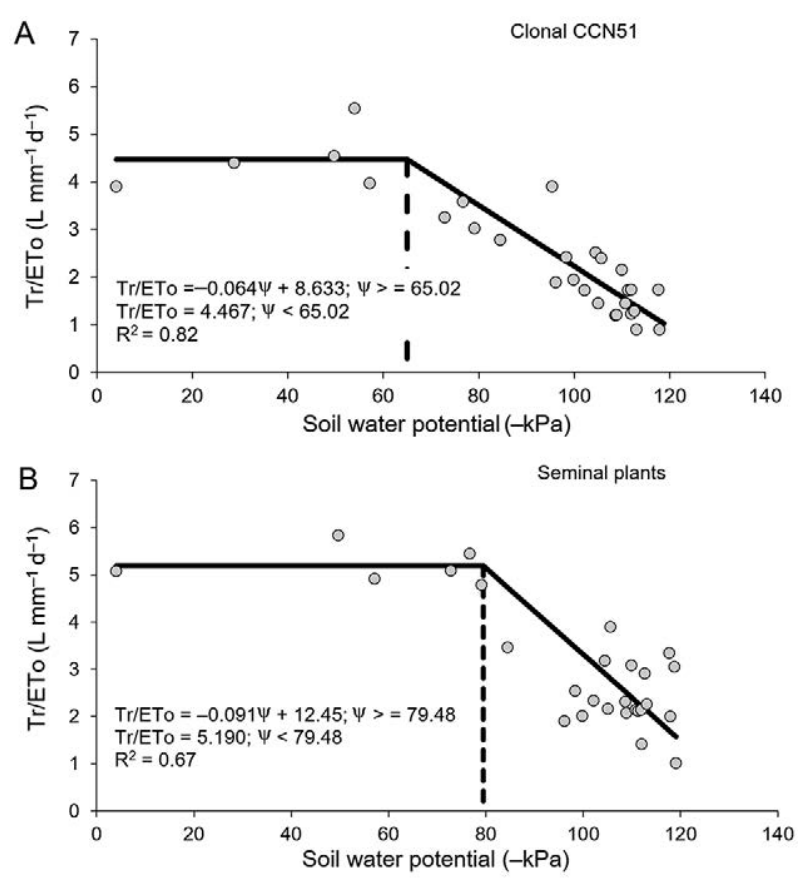

Figure 6 - Relationship between transpiration and reference evapotranspiration ( $\mathrm{Tr} / \mathrm{ETo}$ ) in $\mathrm{CCN} 51$ clones (A) and seminal plants $(B)$ of cocoa trees at different soil matric potentials.

is inferior to $60 \%$ of its total available capacity (Almeida and Valle, 2007); up to this point, as an acclimatization strategy against drought effects, senescence (Santos et al., 2016; Muller et al., 2011) gradually occurs from the lower to the upper leaves (Blum, 2009).

Regardless of the time considered throughout the field experiment, it could be seen that seminal plants maintained Tr/ETo ratios higher than those of the CCN51 clones, and the reduction in these ratios also occurs at lower soil matric potentials, suggesting that the clonal plants are more sensitive to soil water variations. However, the reduction in Tr/ETo above the critical potentials was more accentuated in seminal plants than in clonal plants.

In the greenhouse, plants under frequent irrigation showed higher transpiration levels than those under drying soil conditions. This was an expected result, since the cocoa tree is considered as sensitive to water deficit

Table 4 - Regression analysis between observed and estimated transpiration by the segmented regression model in clonal and seminal cocoa plants in the field experiment.

\begin{tabular}{|c|c|c|c|}
\hline \multicolumn{2}{|l|}{ Clonal CCN51 } & \multicolumn{2}{|c|}{ Seminal } \\
\hline Intercept (a) \pm SD & $0.10800 \pm 0.22430$ & Estimate $a \pm S D$ & $0.36743 \pm 0.38173$ \\
\hline Slope (b) \pm SD & $0.93993 \pm 0.08248$ & Estimate $b \pm S D$ & $0.84475 \pm 0.11385$ \\
\hline Adjusted $\mathrm{R}^{2}$ & 0.82149 & Adjusted $\mathrm{R}^{2}$ & 0.66687 \\
\hline RMSE & 0.52740 & RMSE & 0.78859 \\
\hline $\begin{array}{l}p \text { value for } \\
\mathrm{HO}: \mathrm{a}=0 \text { and } b=1\end{array}$ & 0.71176 & $\begin{array}{c}p \text { value for } \\
\mathrm{HO}: \mathrm{a}=0 \text { and } b=1\end{array}$ & 0.31415 \\
\hline
\end{tabular}

$\mathrm{SD}=$ Standard Deviation; RMSE = Mean Square Root Error. 
(Bae et al., 2008; Moser et al., 2010; Carr and Lockwood, 2011). In addition to the reduction in transpiration caused by leaf senescence, Rada et al. (2005) and Almeida et al. (2016) highlighted possible reductions in photosynthesis and transpiration rates after the soil water variation (water restriction), which were triggered by the sensitivity of the cocoa tree root system, given its high capacity to recognize and respond to changes in physical-chemical soil parameters, especially water limitation (Fageria, 2012).

The stomatal control was evaluated by Rada et al. (2005), in a study carried out in the semi-arid region of Venezuela with plants grown in the shade from the 4-year-old Guasare cultivar, irrigated every 3, 12 or 25 days. In severely stressed plants, daily photosynthesis was reduced by $25 \%$ and transpiration by $39 \%$ compared to the three day treatment. As regards the expected transpiration percentage (Figure 4), a value of $100 \%$ at potential above the critical level $(-24.89 \mathrm{kPa})$ was expected, but the percentage observed was $109 \%$, which is considered an acceptable difference because of the natural variability in this kind of experiment. These natural variabilities, especially those associated with soil water dynamics, are widely discussed by Niether et al. (2017). With an average potential of -59.5 $\mathrm{kPa}$, the expected transpiration had a minimum value of $52 \%$, meaning a reduction of $47 \%$ in the average transpiration. According to these results, the sensitivity of the cocoa tree to water deficit under the experimental conditions is evident because critical values of soil matric potential up to $-100 \mathrm{kPa}$, for a number of woody plants, are commonly assumed in the literature for irrigation management.

Considering the results found in the greenhouse, a decline in the expected transpiration can be seen at potentials lower than $-24.84 \mathrm{kPa}$, when compared to those found in the field $(-79.48 \mathrm{kPa}$ in seminal plants and $-65.02 \mathrm{kPa}$ in clonal plants), showing that plants in the greenhouse were considerably more sensitive to soil water variations, probably because they were young plants whose root system did not yet explore a large volume or depth of soil, or even the low capacity of water storage in their cellular tissues.

The growth and development of the plants depend, among other factors, on the way they respond to the water conditions of the soil-plant-atmosphere system. Thus, the results of the present study indicate that high-frequency irrigation systems, such as microirrigation and pulse drip irrigation, combined with management strategies such as deficit irrigation, ought to offer significant advantages for cocoa tree production.

\section{Conclusion}

For young plants of cocoa tree, clone CCN51, submitted to frequent irrigation, daily mean transpiration varies linearly with ETo. There is a linear reduction in cocoa transpiration due to the decrease in soil matric potential from a critical point. These critical potential values were shown to be variable depending on planting conditions, age of plants and varieties used, ranging from $-24.89 \mathrm{kPa}$ for young cocoa plants in protected environment, to $-79.48 \mathrm{kPa}$ for seedlings under field conditions.

\section{Authors' Contributions}

Conceptualization: Fraga Junior, L.S.; Vellame, L.M.; Paz, V.P.S. Data acquisition: Fraga Junior, L.S.; Vellame, L.M.; Oliveira, A.S. Data analysis: Fraga Junior, L.S.; Vellame, L.M. Design of methodology: Fraga Junior, L.S.; Vellame, L.M.; Oliveira, A.S.; Paz, V.P.S. Writing and editing: Fraga Junior, L.S.; Vellame, L.M.; Paz, V.P.S.; Oliveira, A.S.

\section{References}

Allen, R.G.; Pereira, L.S.; Raes, D.; Smith, M. 1998. Crop Evapotranspiration: Guidelines for Computing Crop Water Requirements. FAO, Rome, Italy. (FAO Irrigation and Drainage Paper, 56).

Almeida, A.-A. F.; Valle, R.R. 2007. Ecophysiology of the cacao tree. Brazilian Journal of Plant Physiology 19: 425-448.

Almeida, J.; Tereza, W.; Herrera, A. 2016. Physiological responses to drought and experimental water deficit and waterlogging of four clones of cacao (Theobroma cacao L.) selected for cultivation in Venezuela. Agricultural Water Management 171: 80-88.

Bae, H.; Kim, S.H.; Kim, M.S.; Sicher, R.C.; Lary, D.; Strem, M.D.; Bailey, B.A. 2008. The drought response of Theobroma cacao (cacao) and the regulation of genes involved in polyamine biosynthesis by drought and other stresses. Plant Physiology and Biochemistry 46: 174-188.

Baligar, V.C.; Bunce, J.A.; Machado, R.C.R.; Elson, M.K. 2008. Photosynthetic photon flux density, carbon dioxide concentration, and vapor pressure deficit effects on photosynthesis in cacao seedlings. Photosynthetica 46: 216221.

Blum, A. 2009. Effective use of water (EUW) and not water-use efficiency (WUE) is the target of crop yield improvement under drought stress. Fields Crops Research 112: 119-123.

Borden, K.A.; Isaac, M.E. 2019. Management strategies differentially affect root functional trait expression in cocoa agroforestry systems. Agronomy for Sustainable Development 39: 21-29.

Carr, M.K.V.; Lockwood, G. 2011. Water relations and irrigation requirements of cocoa (Theobroma cacao L.): a review. Experimental Agriculture 47: 653-676.

Companhia Nacional de Abastecimento [Conab]. 2018. Cocoa, 2018: Monthly Review; Sept/2018 = Cacau, 2018: Análise Mensal; Setembro/2018. Brasília: Companhia Nacional de Abastecimento. Available at: https://www.conab.gov.br/infoagro/analises-do-mercado-agropecuario-e-extrativista/analisesdo-mercado/historico-mensal-de-cacau [Accessed Jun 2, 2018] (in Portuguese). 
Dubreuil, V; Fante, k; Planchon, O; Santa'Anna Neto, J. L. 2017. The types of annual climates in Brazil: an application of the classification of Köppen from 1961 to 2015 = Les types de climats annuels au Brésil : une application de la classification de Köppen de 1961 à 2015. EchoGéo 41: 63-97 (in French).

Fageria, N.K. 2012. The role of plant roots in crop production. CRC Press. Boca Raton, FL, USA.

Granier, A. 1985. A new method for the measurement of sap flow in tree trunks = Une nouvelle méthode pour la mesure des flux de sève brute dans le tronc des arbres. Annales des Sciences Forestières 42: 193-200 (in French).

International Cocoa Organization [ICCO]. 2017. Annual Report. ICCO, Utrecht, The Netherlands.

Köhler, M.; Dierick, D.; Schwendenmann, L.; Hölscher, D. 2009. Water use characteristics of cacao and Gliricidia trees in an agroforest in Central Sulawesi. Ecohydrology 2: 520-529.

Ledieu, J.; De Ridder, P.; De Clerck, P.; Dautrebande, S. 1986. A method for measuring soil water moisture by time-domain reflectometry. Journal of Hydrology 88: 319-328.

Leite, P.B.; Lannes, S.C.S.; Rodrigues, A.M.; Soares, F.A.S.M.; Soares, S.E.; Bispo, E.S. 2013. Rheological study of chocolates made with different cocoa (Theobroma cacao L.) varieties. Brazilian Journal of Food Technology 16: 192-197 (in Portuguese, with abstract in English).

Mayer, D.G.; Stuart, M.A.; Swain, A.J. 1994. Regression of realworld data on model output: an appropriate overall test of validity. Agricultural Systems 45: 93-104.

Moser, G.; Leuschner, C.; Hertel, D.; Hölscher, D.; Köhler, M.; Leitner, D.; Schwendenmann, L. 2010. Response of cocoa trees (Theobroma cacao) to a 13-month desiccation period in Sulawesi. Agroforestry systems 79: 171-187.
Muller, B.; Pantin, F.; Génard, M.; Turc, O.; Freixes, S.; Piques, M.; Gibon, Y. 2011. Water deficits uncouple growth from photosynthesis, increase $\mathrm{C}$ content, and modify the relationships between $\mathrm{C}$ and growth in sink organs. Journal of Experimental Botany 62: 1715-1729.

Niether, W.; Schneidewind, U.; Armengot, L.; Adamtey, N.; Schneider, M.; Gerold, G. 2017. Spatial-temporal soil moisture dynamics under different cocoa production systems. Catena 158: 340-349.

Rada, F.; Jaimez, R.E.; Garcia-Núñez, C.; Azócar, A.; Ramirez, M.E. 2005. Water relations and gas exchange in Theobroma cacao var. Guasare under periods of water deficit. Revista de la Facultad de Agronomia 22: 112-120.

Richards, L.A. 1965. Physical conditions of water in soil. p. 128152. In: Black, C.A.; Evans, D.D.; White, J.L.; Clark, F.E., eds. Methods of soil analysis: physical and mineralogical properties, including statistics of measurements and sampling. ASA/SSSA, Madison, WI, USA.

Santos, E.A.; Almeida, A.-A.F.; Ahnert, D.; Branco, M.C.S.; Valle, R.R.; Baligar, V.C. 2016. Diallel analysis and growth parameters as selection tools for drought tolerance in young Theobroma cacao plants. Plos ONE 11: e0160647.

Vellame, L.M.; Coelho, R.D.; Tolentino, J.B. 2012. Transpiration of young plants of valencia orange in rootstock rangpur and swingle in two types of soil. Revista Brasileira de Fruticultura 34: 24-32 (in Portuguese, with abstract in English).

Vellame, L.M.; Fraga Junior, E.F.; Coelho, R.D. 2015. Effect of partial soil wetting on transpiration, vegetative growth and root system of young orange trees. Scientia Agricola 72: 377-384.

Wang, G.; Liu, F.; Xue, S. 2017. Nitrogen addition enhanced water uptake by affecting fine root morphology and coarse root anatomy of Chinese pine seedlings. Plant and Soil 418: 177-189. 